\title{
Population Variability and Heat Bias Prediction in a Tropical Country, Nigeria, From 2006 to 2036
}

\author{
Nwaerema Peace, Edokpa David \\ Department of Geography and Environmental Management, Faculty of Social Sciences, \\ University of Port Harcourt, Nigeria. \\ * Corresponding author email: udoson326788@yahoo.co.uk \\ Received: 13 August 2018 / Revised: 07 November 2018 / Accepted: 08 November 2018 / Published: 15 November 2018
}

\begin{abstract}
This research explores population variability and heat bias prediction in a tropical country, Nigeria from 2006 to 2036. Data were generated from the projections of the National Population Commission (NPC) using the population mathematical model for heat bias data. With national population growth rate of $2.67 \%$, Nigeria recorded heat bias of $6^{\circ} \mathrm{C}$ in $2016,6.1^{\circ} \mathrm{C}$ in 2026 and $6.2^{\circ} \mathrm{C}$ in 2036 as well as $0.1^{\circ} \mathrm{C}$ decadal variation indicating that it has exceeded the $0.5-0.25^{\circ} \mathrm{C}$ standard comfort threshold. The analytical results show that there is a positive association between population density and heat bias across the states of Nigeria with greater effects in states such as Lagos, Anambra, Imo, Abia, Akwa Ibom Ekiti, Rivers, Osun and Ebonyi due to the high concentration of people in their limited land mass. And more of the eastern states of Nigeria will have much effect of the heat bias due to their high population density. It shows that land mass does not have any association with heat bias and will likely be influenced by land modification and atmospheric characteristics. Heat wave could result to death of people; therefore, national planners should implement environmental, health and land-use management strategies with immediate action in order to make Nigeria a safe place to live.

Keywords: Heat Bias, Heat Island, Land Mass, Nigeria, Population, Population Density, States
\end{abstract}

\section{Introduction}

Heat Island (HI) which is synonymous with Heat Bias (HB) in this context occurs when the built-up area has higher temperature compared to the extended undeveloped natural fringes due to urban pavement materials and other anthropogenic activities. The difference in temperature between built-up and rural fringes is due to variation in quantity of energy gained and released within the urban building materials, such as concrete and asphalt [1]. Heat Island sources are from urban fabrics and those directly generated by man's activities which vary in warm and cold seasons [2]. The undeveloped rural fringes are occupied by vegetation capable of absorbing solar energy in the process of photosynthesis thereby releasing water vapor into the ambient air. The urban area has more concentration of people and pavement materials thereby raising the temperature of the urban area above the rural outskirts. Many variables have contributed to temperature increment in the form of material albedo, decline in tree cover, concentration of urban fabrics, thermal performance of urban fabrics, urban canyon and morphology, size of city area, release of green gas and general manmade heat from other economic activities [3].

When temperature of the city is raised above the comfort threshold, more energy is demanded in air conditioning facilities thereby releasing greater heat to the neighborhood. Water bodies in the city will remain warm with increased temperature thereby reducing water quality and risking the lives of aquatic organisms as well as water demand by man. Air pollutants react faster during temperature rise causing more harm to living things. Temperature of urban landscape is raised by increased energy demand with attendant health and environmental disaster [4]. Heat island has caused discomfort in the cities where oppressive heat and stress caused 692 excess deaths from June to August of 1995 in Chicago, United States [5]. Effects of UHI are rarely noticed by city dwellers due to its similar characteristics with climate change. As a result, little or no attention is giving to managing city warming in developing countries. Also, with the already 
Population V ariability and Heat Bias Prediction in a Tropical Country, Nigeria, From 2006 to 2036

existing intense heat in tropical countries, they are more at risk of heat island due to serious issues with built-up areas, low greening, alteration of city canopy and boundary layers etc [6]. Anthropogenic activities have caused deforestation and general alteration of ground cover by modifying the albedo, surface roughness, thermal and moisture behaviors. Also, anthropogenic modification alters the biophysical properties and in turn affects the local climate through changes in the surface energy balance [7].

With rising population of the world in rural and urban areas, heat island is on the increase. It is estimated that $55 \%$ of the world population is leaving in the urban area and $68 \%$ is expected to leave in the cities in the year 2050 [8]. With increased current population of Nigeria at 197,375,677 persons [9], it is expected that heat island produced by man's activities is on the increase across the various states of the country. It will be interesting to examine the pattern of population growth and prediction of the resultant heat for proper national planning that will meet standard comfort threshold across various cities and rural areas in Nigeria states.

Many studies have been conducted by measuring temperature differences (heat islands) between urban and rural environments [10] [11] [12]. Heat island has not been extensively explored at regional, national, continental and global scales especially in tropical African countries like Nigeria. It is pertinent to begin investigating anthropogenic heat with rise in population in a larger scale beyond the urban area and rural fringes due its subtle impact on the global climate change, heat stress and rescue. In this vein, this research relies on population variability to generate heat bias using the population mathematical model. Also, it statistically analyzed the interactions of generated anthropogenic heat with population density and landmass in all the states of Nigeria, in the West African region.

\section{Materials and Method}

\subsection{Description of Study Location}

The geographical coordinates of Nigeria are $3^{\circ}$ and $14^{\circ}$ East Longitude and $4^{\circ}$ and $14^{\circ}$ North Latitude. East to west distance is about 767 kilometers and north to south has distance of 1,605 kilometers. Nigeria is located in West African region extending to the east and north hemispheres. The country has borders with Benin in the west, Niger in the north, Chad in the north-eastern part, Cameroon in the core east and the Atlantic Ocean in the southern part Figure 1.

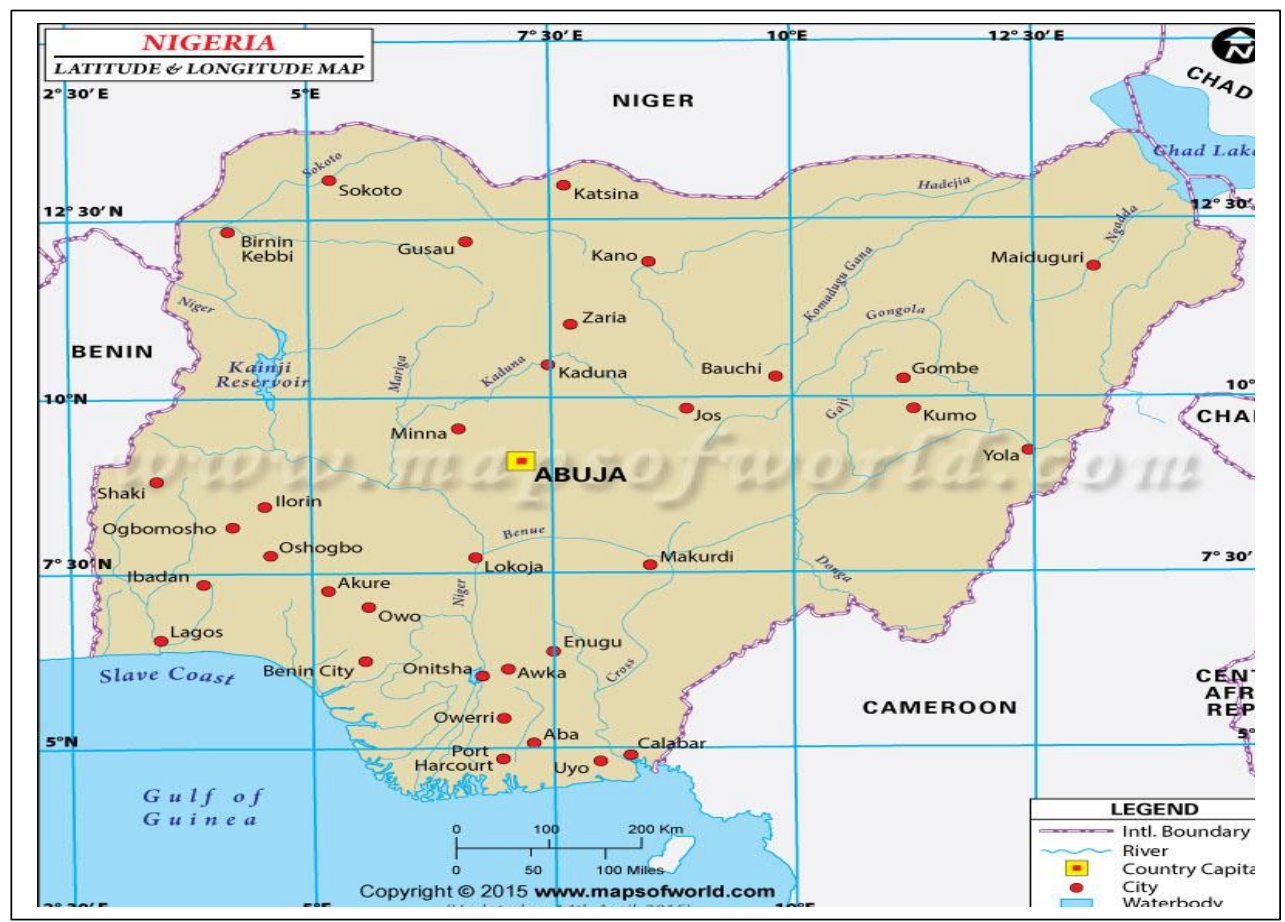

Figure 1: Nigeria Location Map (Source: World Maps). 
Peace.et al., Adv. J Social Sci.; Vol. 4 Issue 1, pp: 28-38, 2019

Nigeria has total area coverage of $923,768 \mathrm{~km}^{2}$ with land area of $910,768 \mathrm{~km}^{2}$ and $13,000 \mathrm{~km}^{2}$ water cover [13]. The country is divided by two major rivers, Niger and Benue facilitating exchange of land and sea breezes in the interior land features. Nigeria is the largest country in Africa ranking the eight most populated in the world. With $186,053,386$ persons, the population density is $204.28 / \mathrm{km}^{2}$ indicating the number of persons modifying biophysical features of the environment per kilometer square. With reduction in birth rate, the country population is projected to grow to 239 million persons in 2025 and by 2050 it will attain 440 million persons which will make it the $4^{\text {th }}$ most populous country in the world. Nigeria urban population is rising above the rural population [14].

The economy of Nigeria is dependent on oil and gas with about $90 \%$ of export earnings. It is the largest crude oil producer in Africa and the $8^{\text {th }}$ in the world exporting $1.59-1.65$ million barrels per day taking place in the southern region of the country. In agriculture, Nigeria employs $65 \%$ of the population. Recently, practice of farming has dropped due to over-dependent on oil and intense migration to the cities. Livestock is produced in the northern part of the country. Domestic fish catch is estimated at 450,000 metric tons per year and annual consumption of 1.5 million tons annually [16]. Over $90 \%$ of rural Nigerians have unreliable or no electricity at all but depend on wood resources are used for cooking [17]. The general economic activities and population growth rate show greater impact of deforestation and anthropogenic heat release in Nigeria.

In the far southern part of Nigeria, mean maximum temperature is about $32^{\circ} \mathrm{C}$ and in the northern part it is at $41^{\circ} \mathrm{C}$. The mean minimum temperature in the south is $21^{\circ} \mathrm{C}$ and $13^{\circ} \mathrm{C}$ in the north. Nigeria records mean temperature of $27^{\circ} \mathrm{C}$ without any altitudinal modifications. Global warming is a contemporary challenge facing the world including Nigeria. The annual rainfall is $2300 \mathrm{~mm}$. It is $2,500 \mathrm{~mm}$ in the south and low with $400 \mathrm{~mm}$ in the extreme northern parts like Maiduguri [18][3]. Nigeria has two main tropical climates of wet and dry seasons. In the south, wet season occurs from March to November and in the north from May to October. The remaining months are occupied by dry season [19].

Nigerian Climate varies from humid, sub-humid, semi-arid and arid zones which give rise to sub-seasons of long wet season, short dry season, short wet season and long dry season respectively (Figures 2).

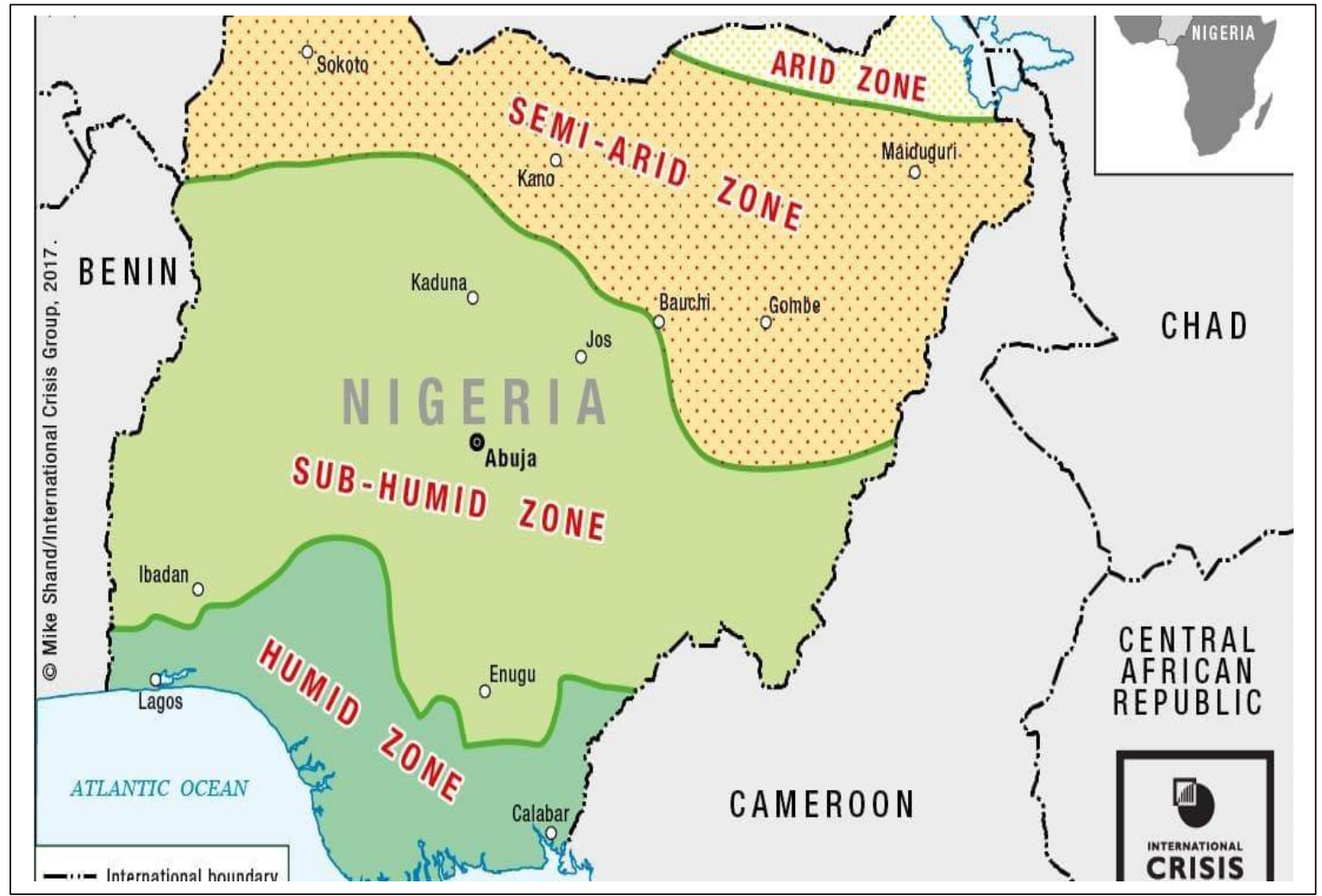

Figure 2: Nigeria Climate Zones 


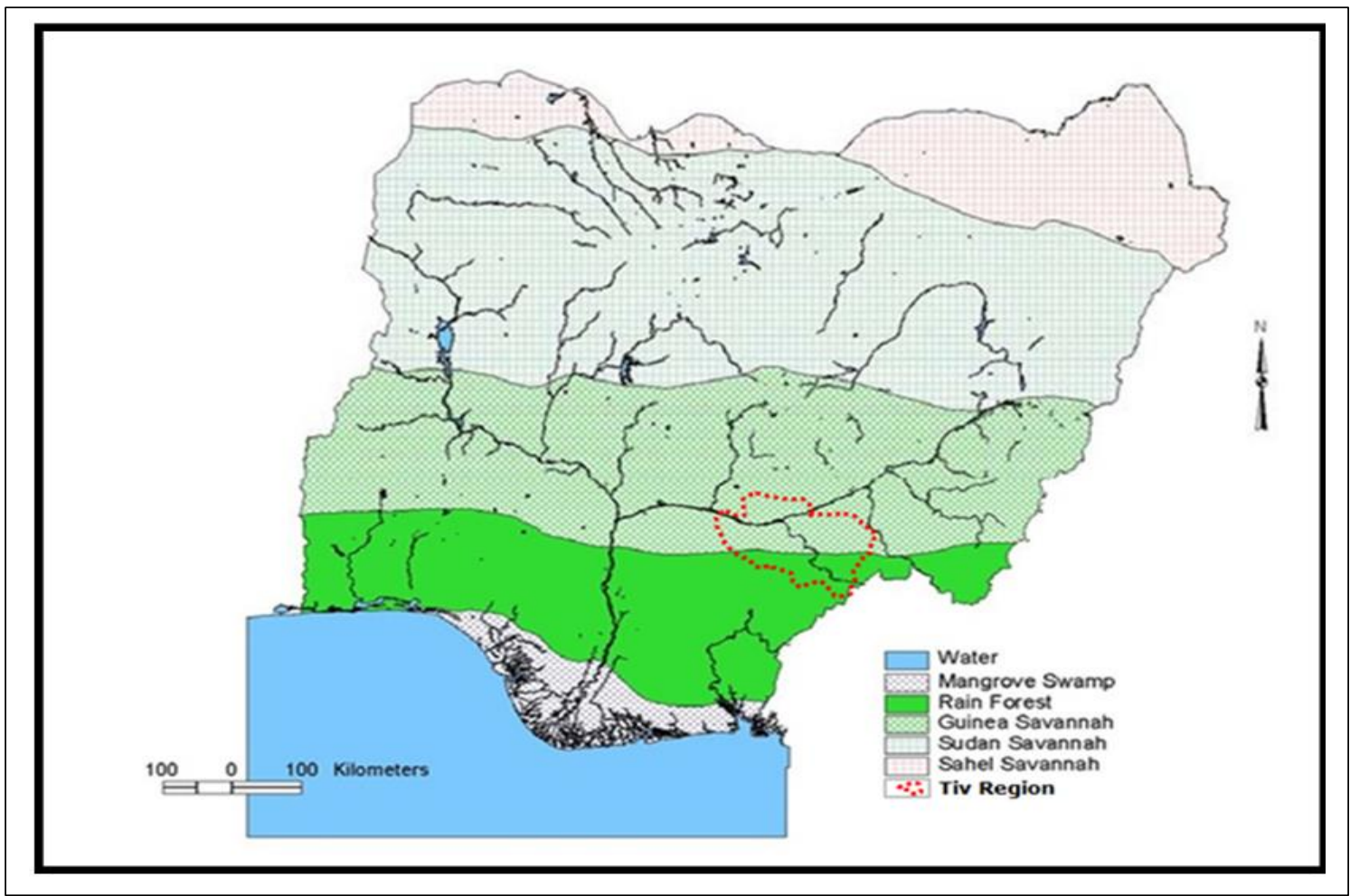

Figure 3: Nigeria Climatic Belts

It can be classified according to vegetal cover of Guinea, Sudan and Sahel savanna, Mangrove as well as Rain Forests (Figure 3). Rainfall occurrence is higher in the south than the north making the southern part have more water bodies necessary for air temperature and moisture moderation.

\subsection{Methods of Data Collection}

This assessment is based on secondary data. For population data, they were collected from records of National Population Commission (NPC) 2006 and projected up to 2036 with growth rate of $2.67 \%$ across the states. Data for heat island were generated from population records using the population mathematical model of [20]. The development of heat island is tied to population of a place which can be used as prediction model for generalization in climatic modeling, urban planning and weather forecasting. The heat island in Degree Celsius $\left({ }^{\circ} \mathrm{C}\right)$ increases with population according to the formula:

Heat Island $=0.73 \log _{10}$ Pop

Where: Pop denotes population.

Adopting the formula, [20] [21] were of the opinion that a settlement with 10 persons has heat island of $1.46^{\circ} \mathrm{C}$ and settlement with 1000 persons has a heat island of $2.2^{\circ} \mathrm{C}$ as well as a large city with a million people has heat island of $4.4^{\circ} \mathrm{C}$. The population mathematical model was used to generate data for predicting heat island in the 36 States of Nigeria. Descriptive statistics such as mean and range were used for the analysis. Paired t-test was adopted to establish if there is variation of heat bias in thirty years interval (2006 and 2036). Pearson product moment correlation coefficient was applied to know whether there are differences between heat bias and population density, heat bias and land mass across the states.

\section{Results and Discussion}

\subsection{Population characteristics and Heat Bias}

Rapid and uncontrolled population growth is a threat to the human environment in Nigeria. The country (Figure 4) has annual heat bias of $6^{\circ} \mathrm{C}$ in 2006 to $2016,6.1^{\circ} \mathrm{C}$ in 2016 and $6.2^{\circ} \mathrm{C}$ in 2036 respectively. It recorded constant heat bias difference of $0.6^{\circ} \mathrm{C}$ between states with highest and lowest records per decade 
Peace.et al., Adv. J Social Sci.; Vol. 4 Issue 1, pp: 28-38, 2019

(Table 1). Nigeria generated average heat bias of $5.8^{\circ} \mathrm{C}$ in $2006,5.9^{\circ} \mathrm{C}$ in 2016 and steadily maintained $5^{\circ} \mathrm{C}$ in 2026 and 2036 across the states. The distribution of heat bias across the States in Nigeria is displayed in Figure 5.

Table 1: Population and Heat Bias across the States in Nigeria

\begin{tabular}{|c|c|c|c|c|c|c|c|c|c|}
\hline $\mathbf{S} / \mathbf{N}$ & States & 2006 & $\begin{array}{l}\text { Heat } \\
\text { Bias } \\
\left({ }^{\circ} \mathrm{C}\right)\end{array}$ & 2016 & $\begin{array}{l}\text { Heat } \\
\text { Bias } \\
\quad\left({ }^{\circ} \mathbf{C}\right)\end{array}$ & 2026 & $\begin{array}{l}\text { Heat } \\
\text { Bias } \\
\left({ }^{\circ} \mathrm{C}\right)\end{array}$ & 2036 & $\begin{array}{l}\text { Heat } \\
\text { Bias } \\
\quad\left({ }^{\circ} \mathrm{C}\right)\end{array}$ \\
\hline 1 & Kano & $9,401,288$ & 5.1 & $11,911,431$ & 5.2 & $15,091,783$ & 5.2 & $19,121,289$ & 5.3 \\
\hline 2 & Lagos & $9,113,605$ & 5.1 & $11,546,937$ & 5.2 & $14,606,875$ & 5.2 & $18,506,910$ & 5.3 \\
\hline 3 & Kaduna & $6,113,503$ & 5 & $7,751,148$ & 5 & $9,820,704$ & 5.1 & $12,442,831$ & 5.2 \\
\hline 4 & Katsina & $5,801,584$ & 5 & $7,350,607$ & 5 & $9,313,219$ & 5.1 & $11,799,848$ & 5.2 \\
\hline 5 & Оуо & $5,580,894$ & 5 & 7,070,992 & 5 & $8,958,946$ & 5.1 & $11,350,984$ & 5.2 \\
\hline 6 & Rivers & $5,198,716$ & 5 & $6,586,773$ & 5 & $8,345,441$ & 5.1 & $10,573,673$ & 5.1 \\
\hline 7 & Bauchi & $4,653,066$ & 4.9 & $5,895,434$ & 5 & $7,469,514$ & 5 & $9,463,874$ & 5.1 \\
\hline 8 & Jigawa & $4,361,002$ & 4.8 & $5,525,389$ & 5 & $7,000,667$ & 5 & $8,869,845$ & 5.1 \\
\hline 9 & Benue & $4,253,641$ & 4.8 & $5,389,363$ & 5 & $6,828,323$ & 5 & $8,651,485$ & 5.1 \\
\hline 10 & Anambra & $4,177,828$ & 4.8 & $5,293,308$ & 5 & $6,706,621$ & 5 & $8,497,288$ & 5.1 \\
\hline 11 & Borno & $4,171,104$ & 4.8 & $5,284,788$ & 5 & $6,695,826$ & 5 & $8,483,611$ & 5.1 \\
\hline 12 & Delta & $4,112,445$ & 4.8 & $5,210,467$ & 5 & $6,601,661$ & 5 & $8,364,304$ & 5.1 \\
\hline 13 & Niger & $3,954,772$ & 4.8 & $5,010,696$ & 4.9 & $6,348,551$ & 5 & $8,043,614$ & 5 \\
\hline 14 & Imo & $3,927,563$ & 4.8 & $4,976,222$ & 4.9 & $6,304,873$ & 5 & $7,988,274$ & 5 \\
\hline 15 & $\begin{array}{l}\text { Akwa } \\
\text { Ibom }\end{array}$ & $3,902,051$ & 4.8 & $4,943,898$ & 4.9 & $6,263,918$ & 5 & 7,936,384 & 5 \\
\hline 16 & Ogun & $3,751,140$ & 4.8 & $4,752,694$ & 4.9 & $6,021,663$ & 5 & $7,629,447$ & 5 \\
\hline 17 & Sokoto & $3,702,676$ & 4.8 & $4,691,290$ & 4.9 & $5,943,864$ & 5 & $7,530,875$ & 5 \\
\hline 18 & Ondo & $3,460,877$ & 4.7 & 4,384,931 & 4.8 & $5,555,707$ & 5 & $7,039,080$ & 5 \\
\hline 19 & Osun & $3,416,959$ & 4.7 & $4,329,287$ & 4.8 & $5,485,206$ & 5 & $6,949,756$ & 5 \\
\hline 20 & Kogi & $3,314,043$ & 4.7 & $4,198,892$ & 4.8 & $5,319,996$ & 5 & $6,740,434$ & 5 \\
\hline 21 & Zamfara & $3,278,873$ & 4.7 & $4,154,332$ & 4.8 & $5,263,538$ & 5 & $6,668,902$ & 5 \\
\hline 22 & Enugu & $3,267,837$ & 4.7 & $4,140,349$ & 4.8 & $5,245,822$ & 5 & $6,646,456$ & 5 \\
\hline 23 & Kebi & $3,256,541$ & 4.7 & $4,126,037$ & 4.8 & $5,227,688$ & 5 & $6,623,480$ & 5 \\
\hline 24 & Edo & $3,233,366$ & 4.7 & $4,096,674$ & 4.8 & $5,190,486$ & 5 & $6,576,345$ & 5 \\
\hline 25 & Plateau & $3,206,531$ & 4.7 & $4,062,674$ & 4.8 & $5,147,408$ & 4.9 & $6,521,765$ & 5 \\
\hline 26 & Adamawa & $3,178,950$ & 4.7 & $4,027,729$ & 4.8 & $5,103,132$ & 4.9 & $6,465,668$ & 5 \\
\hline 27 & $\begin{array}{l}\text { Cross } \\
\text { River }\end{array}$ & $2,892,988$ & 4.7 & $3,665,415$ & 4.8 & $4,644,080$ & 4.9 & $5,884,049$ & 5 \\
\hline 28 & Abia & $2,845,380$ & 4.7 & $3,605,096$ & 4.8 & $4,567,656$ & 4.9 & $5,787,220$ & 5 \\
\hline 29 & Ekiti & $2,398,957$ & 4.7 & $3,037,478$ & 4.7 & $3,848,484$ & 4.8 & $4,876,029$ & 4.9 \\
\hline 30 & Kwara & $2,365,353$ & 4.7 & $2,996,902$ & 4.7 & $3,797,074$ & 4.8 & $4,810,892$ & 4.9 \\
\hline 31 & Gombe & $2,365,040$ & 4.7 & $2,996,505$ & 4.7 & $3,796,571$ & 4.8 & $4,810,255$ & 4.9 \\
\hline 32 & Yobe & $2,321,339$ & 4.6 & $2,941,136$ & 4.7 & $3,726,419$ & 4.8 & $4,721,372$ & 4.9 \\
\hline 33 & Taraba & $2,294,800$ & 4.6 & $2,907,511$ & 4.7 & $3,683,816$ & 4.8 & $4,667,394$ & 4.9 \\
\hline 34 & Ebonyi & $2,176,947$ & 4.6 & $2,758,191$ & 4.7 & $3,494,628$ & 4.8 & $4,427,693$ & 4.9 \\
\hline 35 & Nasarawa & $1,869,377$ & 4.6 & $2,368,500$ & 4.7 & $3,000,889.00$ & 4.7 & $3,802,126$ & 4.8 \\
\hline 36 & Bayelsa & $1,704,515$ & 4.5 & $2,159,620$ & 4.6 & $2,736,238$ & 4.7 & $3,466,813$ & 4.8 \\
\hline \multirow[t]{2}{*}{37} & FCT & $1,406,239$ & 4.5 & $1,781,704$ & 4.6 & $2,257,419$ & 4.6 & $2,860,149$ & 4.7 \\
\hline & Total & $140,431,790$ & 6 & $177,930,400$ & 6 & $225,414,706$ & 6.1 & $285,600,414$ & 6.2 \\
\hline
\end{tabular}




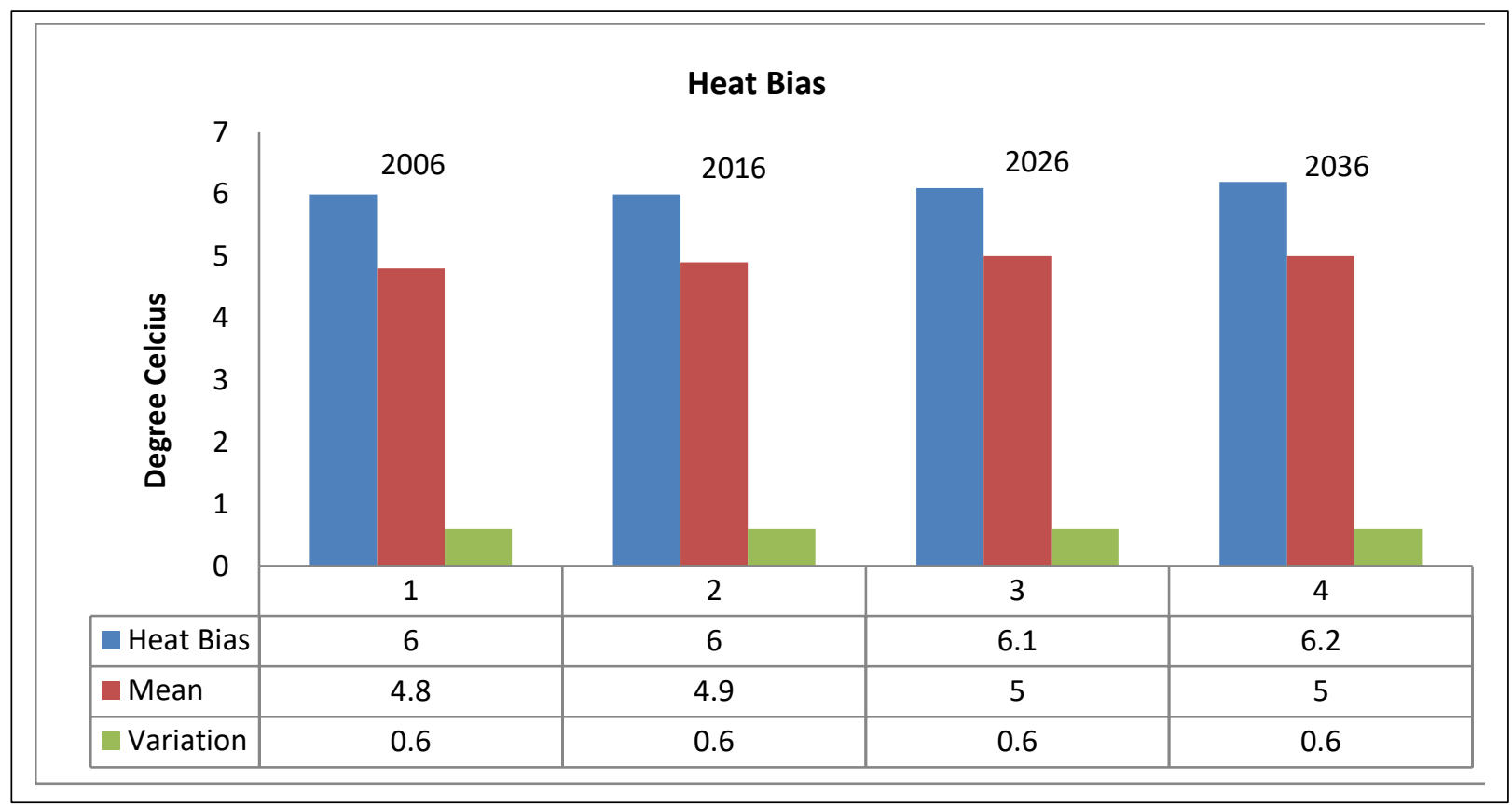

Figure 4: States Mean and Variation of Heat Bias in Nigeria

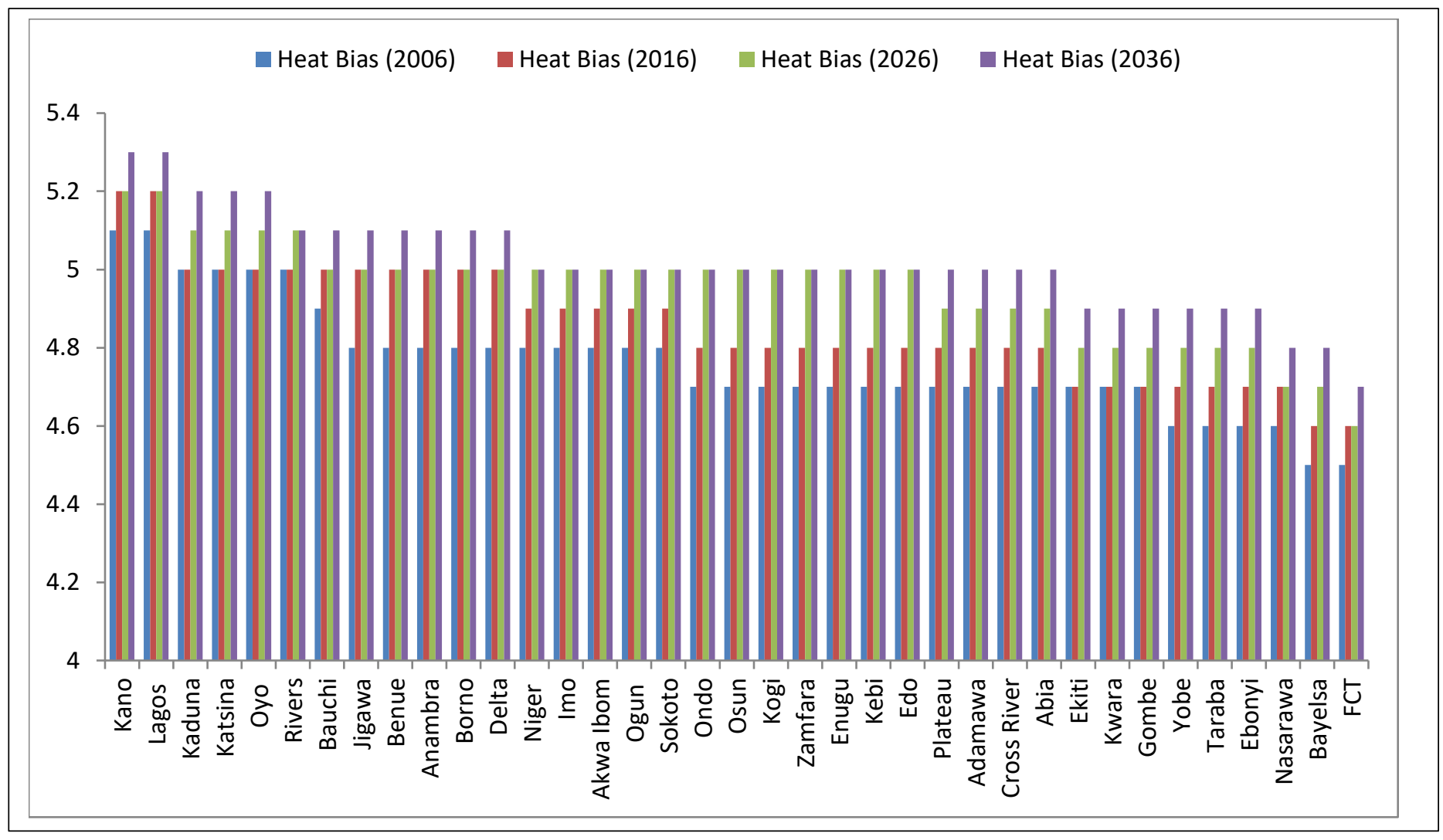

Figure 5: Decadal Distribution of Heat Bias across States in Nigeria (2006 - 2036)

Kano and Lagos States have the highest population and heat bias in Nigeria (Table 1). In 2006 Kano and Lagos States had population of 9,401,288 and 9,113,605 and heat bias of $5.1^{\circ} \mathrm{C}$ each respectively. Heat bias of the two states changed to $5.2^{\circ} \mathrm{C}$ in 2016 and remained constant till 2026 and recorded another increment of $5.3^{\circ} \mathrm{C}$ in 2036 with variation of $0.1^{\circ} \mathrm{C}$ across the decades. Lagos heat bias will be moderated by the Atlantic Ocean moisture content moving to the land (Figure 2). It has cooling advantage of the 
Peace.et al., Adv. J Social Sci.; Vol. 4 Issue 1, pp: 28-38, 2019

humid and rainforest zones of Nigeria (Figures 2 and 3 above). On the other hand, Kano State is landlocked, located in the Semi-Arid and Sudan Savanna zones of Nigeria which will intensify heat discomfort for the inhabitants but heat will be influenced by the free wind flow due to low vegetal cover. Both Kano and Lagos States have exceeded the recommended comfort threshold of $0.5-2.5^{\circ} \mathrm{C}$ [22] indicating that rapid population has compromised heat bias in the states.

Kaduna, Katsina, Oyo and Rivers (Figure 4) have heat bias of $5^{\circ} \mathrm{C}$ in 2006 through 2016 and $5.1^{\circ} \mathrm{C}$ in 2026 as well as $5.2^{\circ} \mathrm{C}$ in 2036 except Rivers State which has $5.1^{\circ} \mathrm{C}$ constant; all with growth rate of $0.1^{\circ} \mathrm{C}$. Heat impact in Oyo and Rivers States will be moderated by their location in humid and mangrove rainforest zones. Kaduna and Katsina in the northern segment of Nigeria will experience intense heat bias due to their locations in the Arid, Semi-arid, Sudan and Sahel Savanna respectively exceeding the acceptable heat island threshold. Their heat bias will be controlled by the intense wind flow systems in the lower troposphere due to poor vegetation.

Bauchi State alone generated heat bias of $4.9^{\circ} \mathrm{C}$ in 2006 with steady heat bias of $5^{\circ} \mathrm{C}$ till 2026 and $5.1^{\circ} \mathrm{C}$ in 2036. Jigawa, Benue, Anambra, Borno and Delta States had heat bias of $4.8^{\circ} \mathrm{C}$ in 2006 and $5^{\circ} \mathrm{C}$ in 2016 to 2026 with a shift to $5.1^{\circ} \mathrm{C}$ in 2036 . Heat stress in Borno and Jigawa is accelerated by intense insolation due to their location in the Arid zone, Sahel and Sudan Savanna respectively which have low moisture content. Heat island is expected to reduce the wind velocity in the savanna. Low heat impact in Benue, Anambra and Delta are influenced by the humid, mangrove and rainforest environment. The states in northern part of Nigeria will relatively experience high impact of heat bias due to their differential vegetal and water body coverage unlike states in the south with high coverage of vegetation and water bodies.

Niger, Imo, Akwa Ibom, Ogun and Sokoto States are in the same heat bias category of $4.8^{\circ} \mathrm{C}$ in $2006,4.9^{\circ} \mathrm{C}$ in 2016 and a constant heat bias of $5^{\circ} \mathrm{C}$ between 2026 to 2036. Sokoto and Niger are located in the Sahel and Sudan Savanna as well as Semi-arid and Sub-humid zones respectively indicating that these states will have high impact of heat bias. Imo, Akwa Ibom and Ogun States have high heat bias but with a favorable land zone of humid and mangrove rainforests of high moisture contents due to rivers and ocean water bodies as well the large expanse of vegetal cover.

Ondo, Osun, Kogi, Zamfara, Enugu, Kebi and Edo are in the same category of heat bias of $4.7^{\circ} \mathrm{C}$ in 2006 , $4.8^{\circ} \mathrm{C}(2016), 5^{\circ} \mathrm{C}(2026)$ and $5^{\circ} \mathrm{C}$ in 2036 . These States have $0.1^{\circ} \mathrm{C}$ decadal variation of heat bias. Zamfara, Kebi and Kogi States are located in the low vegetal low moisture zones of Guinea and Sudan Savanna as well as sub-humid and semi-arid zones of Nigeria. These surface characteristics will intensify heat bias performance in the States. Heat bias in Ondo, Osun, Enugu and Edo will be influenced by their location in the humid and rainforest zones of the country.

Adamawa, Cross Rivers, Abia and Plateau States have common heat bias of $4.7^{\circ} \mathrm{C}$ in $2006,4.8^{\circ} \mathrm{C} 2016$, $4.9^{\circ} \mathrm{C} 2016$ and $5^{\circ} \mathrm{C}$ in 2036 respectively. The states have heat bias change of $0.1^{\circ} \mathrm{C}$ per decade. Zamfara and Plateau will have severe effects of anthropogenic heat due to their location in the Semi-arid and Sudan Savanna. Heat stress will be tolerated in Cross Rivers and Abia States due to the intricate terrain of humid mangrove and rainforests as well as nearness to the Atlantic Ocean that transfer moisture inland.

Ekiti, Kwara and Gombe have identical heat bias performance of $4.7^{\circ} \mathrm{C}$ in 2006 to $2016,4.8^{\circ} \mathrm{C}$ in 2026 and $4.9^{\circ} \mathrm{C}$ in 2036 . Yobe, Taraba and Ebonyi have common heat bias of $4.6^{\circ} \mathrm{C}$ in $2006,4.7^{\circ} \mathrm{C} 2016,4.8^{\circ} \mathrm{C} 2026$ and $4.9^{\circ} \mathrm{C}$ in 2036 . Nasarawa has its particular heat bias growth pattern of $4.6^{\circ} \mathrm{C}$ in $2006,4.7^{\circ} \mathrm{C}$ in 2016 to 2026 and $4.8^{\circ} \mathrm{C}$ in 2036 . Bayelsa has its unique heat bias identification of $4.5^{\circ} \mathrm{C}$ in $2006,4,6^{\circ} \mathrm{C}$ in 2016 through 2026 and $4.8^{\circ} \mathrm{C}$ in 2036 . The Federal Capital Territory (FCT) has heat bias pattern of $4.5^{\circ} \mathrm{C}$ in 2006 , $4.6^{\circ} \mathrm{C}$ in 2016 to 2026 and $4.7^{\circ} \mathrm{C}$ in 2036 . Ekiti, Kwara, Taraba, Nasarawa and FCT will relatively experience greater effects of the Heat bias in the Sub-humid and Guinea Savanna. Gombe State is located within the Semi-Arid and Guinea Savanna with greater heat bias due to low vegetal and water bodies. Ebonyi and Beyesla States will relatively have low effects of the heat bias because of their location in the sub-humid, humid and mangrove rainforest characteristics of the terrain. 


\subsection{Population Density and Heat Bias}

The concentration of people leaving in a particular geographic location has common relationship with generated heat stress. Nigeria has approximate current land mass of about $909,690 \mathrm{Km}^{2}$ and population density of 247.8 persons per square kilometer [22] generating $6^{\circ} \mathrm{C}$ heat bias. Lagos has the highest population density of $3,979 / \mathrm{km}^{2}$ and heat bias of $5.2^{\circ} \mathrm{C}$ (Figures 6 and 7). Other states with the risk of high heat stress due to concentration of people on a kilometer square of land are Anambra with population density of $1,378.52 / \mathrm{Km}^{2}$ and heat bias of $5^{\circ} \mathrm{C}$, Imo $1,192.10 / \mathrm{Km}^{2}$ and $5^{\circ} \mathrm{C}$, Abia $932.17 / \mathrm{Km}^{2}$ and $4.9^{\circ} \mathrm{C}$, Akwa Ibom $907.81 / \mathrm{Km}^{2}$ and $5^{\circ} \mathrm{C}$, Ekiti $708.09 / \mathrm{Km}^{2}$ and $4.8^{\circ} \mathrm{C}$, Rivers $789.67 / \mathrm{Km}^{2}$ and $5.1^{\circ} \mathrm{C}$, Kano $744.17 / \mathrm{Km}^{2}$ and $5.2^{\circ} \mathrm{C}$, Osun $607 / \mathrm{Km}^{2}$ and $5^{\circ} \mathrm{C}$ and Ebonyi $546 / \mathrm{Km}^{2}$ and $4.8^{\circ} \mathrm{C}$. The States in the Eastern part of Nigeria such as Anambra, Imo, Abia and Ebonyi have the tendency to generate more heat bias due to greater number of people occupying smaller land mass. This is followed by south-south states of Rivers and Akwa Ibom respectively. The states with the highest heat bias risk contributed by population density in the west and north are Osun and Kano respectively (Figures 6 and Table 2).

The first hypothesis (Ho) stated that there is no significant variation in heat bias across the decades in Nigeria (2006 to 2036). The student t-test has result value of 3.26168E-11 which is lesser than 0.05 . This indicates that the heat bias from one decade to another in Nigeria differ significantly. This is in tandem with the previous view that heat bias in Nigeria vary at $0.1^{\circ} \mathrm{C}$ per decade.

The second hypothesis (Ho) stated that there is no relationship between heat bias and population density in Nigeria. The Person Product-Moment Correlation Coefficient $\left(\mathrm{r}^{2}\right)$ was applied. The result shows positive correlation value of 0.4 . This indicates a moderate positive relationship of heat bias and population density of the data sets such that as population density increases, heat bias also increases, verse versa. This relationship seems to be caused by the impact of human activities concentrating in a space. It means that the smaller the space of human activities and increased population the higher the heat bias. This is in tandem with the previous view that states such as Lagos, Anambra, Imo, Abia, Akwa Ibom Ekiti, Rivers, Osun and Ebonyi would have severe heat stress due to their population density (Figure 5).

The last hypothesis (Ho) stated that there is no association between land mass and heat bias in Nigeria. The Person Product-Moment Correlation Coefficient $\left(\mathrm{r}^{2}\right)$ was applied. The result shows no correlation value of 0.03 . This shows a negative relationship of land mass and heat bias data sets such that increase in the size of land mass does not result to increase in heat bias. This relationship seems to be caused by the fact that only human activities in a land space can contribute to heat bias and not the idle mass itself. It shows that heat bias is a context of human activities only. This is in tandem with Table 2 that states such as Borno, Niger, Bauchi and Kaduna with land mass of $72,609 \mathrm{Km}^{2}, 68,925 \mathrm{Km}^{2}, 49,119 \mathrm{Km}^{2}$ and $42,481 \mathrm{Km}^{2}$ do not have the highest heat bias in Nigeria but depend on the population of people resident in the states.

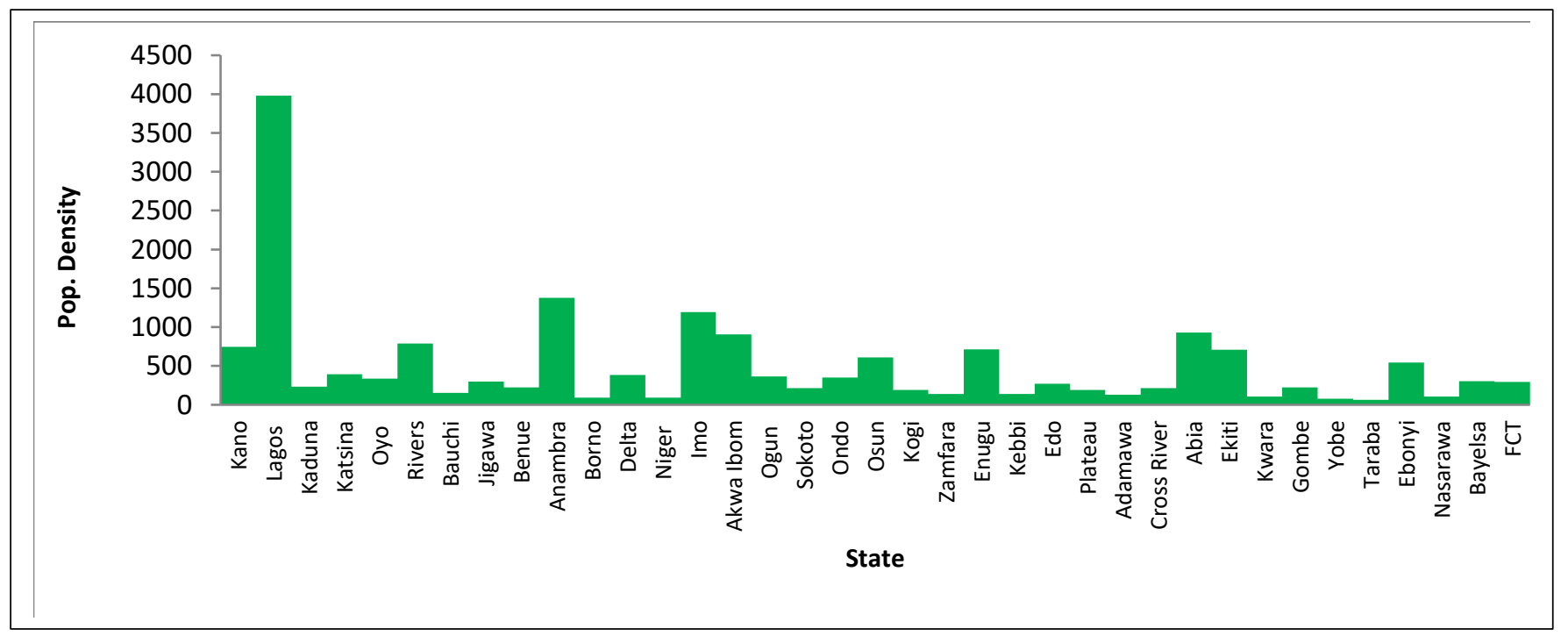

Figure 6: Projected Population Density of States in Nigeria (2016-2026) 
Peace.et al., Adv. J Social Sci.; Vol. 4 Issue 1, pp: 28-38, 2019

Table 2: Land Mass, Population density and heat Bias of Nigeria

\begin{tabular}{|c|c|c|c|c|}
\hline & & 2016 to 2026 & & \\
\hline States & Population & Land Mass & $\begin{array}{c}\text { Population } \\
\text { Density }\end{array}$ & Heat Bias \\
\hline Kano & $15,091,783$ & 20,280 & 744.17 & 5.2 \\
\hline Lagos & $14,606,875$ & 3,671 & 3,979 & 5.2 \\
\hline Kaduna & $9,820,704$ & 42,481 & 231.18 & 5.1 \\
\hline Katsina & $9,313,219$ & 23,561 & 395.28 & 5.1 \\
\hline Oyo & $8,958,946$ & 26,500 & 338.07 & 5.1 \\
\hline Rivers & $8,345,441$ & 10,575 & 789.67 & 5.1 \\
\hline Bauchi & $7,469,514$ & 49,119 & 152.07 & 5 \\
\hline Jigawa & $7,000,667$ & 23,287 & 300.63 & 5 \\
\hline Benue & $6,828,323$ & 30,800 & 221.7 & 5 \\
\hline Anambra & $6,706,621$ & 4,865 & $1,378.54$ & 5 \\
\hline Borno & $6,695,826$ & 72,609 & 92.23 & 5 \\
\hline Delta & $6,601,661$ & 17,108 & 385.88 & 5 \\
\hline Niger & $6,348,551$ & 68,925 & 92.11 & 5 \\
\hline Imo & $6,304,873$ & 5,288 & $1,192.10$ & 5 \\
\hline Akwa Ibom & $6,263,918$ & 6,900 & 907.81 & 5 \\
\hline Ogun & $6,021,663$ & 16,400 & 367.17 & 5 \\
\hline Sokoto & $5,943,864$ & 27,825 & 213.62 & 5 \\
\hline Ondo & $5,555,707$ & 15,820 & 351.82 & 5 \\
\hline Osun & $5,485,206$ & 9,026 & 607.71 & 5 \\
\hline Kogi & $5,319,996$ & 27,747 & 191.73 & 5 \\
\hline Zamfara & $5,263,538$ & 37,931 & 138.77 & 5 \\
\hline Enugu & $5,245,822$ & 7,334 & 715.27 & 5 \\
\hline Kebbi & $5,227,688$ & 36,985 & 141.35 & 5 \\
\hline Edo & $5,190,486$ & 19,187 & 270.52 & 5 \\
\hline Plateau & $5,147,408$ & 27,147 & 189.61 & 4.9 \\
\hline Adamawa & $5,103,132$ & 38,700 & 131.86 & 4.9 \\
\hline Cross River & $4,644,080$ & 21,787 & 213.16 & 4.9 \\
\hline Abia & $4,567,656$ & 4,900 & 932.17 & 4.9 \\
\hline Ekiti & $3,848,484$ & 5,435 & 708.09 & 4.8 \\
\hline Kwara & $3,797,074$ & 35,705 & 106.35 & 4.8 \\
\hline Gombe & $3,796,571$ & 17,100 & 222.02 & 4.8 \\
\hline Yobe & $3,726,419$ & 46,609 & 80 & 4.8 \\
\hline Taraba & $3,683,816$ & 56,282 & 65.45 & 4.8 \\
\hline Ebonyi & $3,494,628$ & 6,400 & 546.04 & 4.8 \\
\hline Nasarawa & $3,000,889$ & 28,735 & 104.43 & 4.7 \\
\hline Bayelsa & $2,736,238$ & 9,059 & 302.05 & 4.7 \\
\hline \multirow[t]{2}{*}{ FCT } & $2,257,419$ & 7,607 & 296.76 & 4.6 \\
\hline & $225,414,706$ & 909,690 & 247.8 & 5 \\
\hline
\end{tabular}




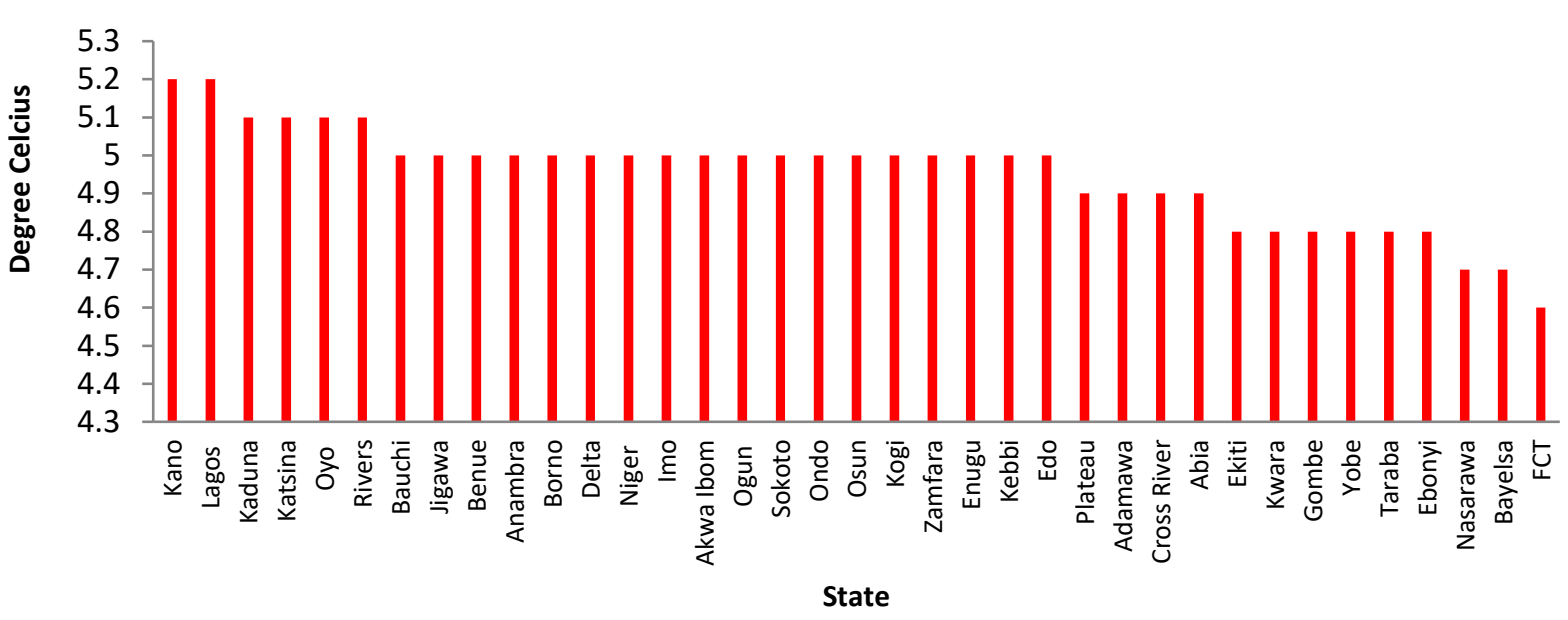

Figure 7: Projected Pattern of Heat Bias of Nigeria States (2016-2026)

\section{Conclusion}

This research explores population variability and heat bias prediction in a tropical country, Nigeria from 2006 to 2036. Heat bias data were generated from population data of 2006 National Population Commission (NPC) using the population mathematical model. With national population growth rate of $2.67 \%$, Nigeria recorded heat bias of $6^{\circ} \mathrm{C}$ in $2016,6.1^{\circ} \mathrm{C}$ in 2026 and $6.2^{\circ} \mathrm{C}$ in 2036 as well as $0.1^{\circ} \mathrm{C}$ decadal growth rate indicating that it has exceeded the $0.5-0.25^{\circ} \mathrm{C}$ standard comfort threshold. The analytical results show that there is positive association between population density and heat bias across the states of Nigeria with greater effects in states such as Lagos, Anambra, Imo, Abia, Akwa Ibom Ekiti, Rivers, Osun and Ebonyi due to high concentration of people in their limited land mass. And more of the eastern states of Nigeria will have much effect of the heat bias due to their high population density. Result shows that land mass does not have any association with heat bias until there are people and activities in the land. Heat bias in the states located in Semi-Arid, Arid, Sudan and Sahel Savanna are likely to have more heat bias impact due to their low vegetal and water body coverage but have their advantage of free and intense wind flow systems. States in the southern part of the country have advantage of high vegetal cover of mangrove and rainforest characteristics as well as water bodies that increase moisture inland. Heat wave that results to stress and death of people is propagated by anthropogenic heat bias and tropical countries have greater risk due to their peculiar high temperature intensity. It is important therefore, that national planners implement environmental, health and land-use planning with immediate action in order to make Nigeria a safe place free from discomforting heat bias.

\section{How to Cite this Article}

Nwaerema, P., \& Edokpa, D. (2018). Population Variability and Heat Bias Prediction in a Tropical Country, Nigeria, From 2006 to 2036. Advanced Journal of Social Science, 4(1), 28-38. https://doi.org/10.21467/ajss.4.1.28-38

\section{References}

[1] David, L. C. (2018, 22 February). Urban heat island effects depend on a city's layout. Physical Review Letters.

[2] Anna, A. S., Darryn, W. W. and Ben, F. Z. (2018, 18 May). Reduced Urban Heat Island intensity under warmer conditions. Environmental Research Letters, 13, 6.

[3] Nwaerema, P. and Nwagbara, M. O. (2018). Spatial and Temporal Variability of Weekday Urban Heat Island in Port Harcourt and Environs. The International Journal of Science and Technoledge, 6, (3).

[4] Abbas, M, Jason, B and Tristan, J (2017). The urban heat island effect, its causes, and mitigation, with reference to the thermal properties of asphalt concrete. Journal of Environmental Management, 197.

[5] Reinhard, K., Alain, L., Joel, S., Carol, A. G., Randolph, W. D., and Carol, Rubin, H. (April, 2017). The Effect of the 1995 Heat Wave in Chicago on All-Cause and Cause-Specific Mortality. American Public Health Association. 
Peace.et al., Adv. J Social Sci.; Vol. 4 Issue 1, pp: 28-38, 2019

[6] Nwaerema, P. and Weli, V.E. (2018). Urban Warming in Port Harcourt Metropolis and Environs. Journal of Geography, Environment and Earth Science International, 14(4).

[7] Gregory, D., Giovanni, F., Eddy, R., Wei, L., Goran, G., Peter, L., Andy, W., Philippe, C., Julia, P., Stephen, S., Almut, A. and Alessandro, C. (2018). Biophysics and vegetation cover change: a process-based evaluation framework for confronting land surface models with satellite observations. Earth Syst. Sci. Data, 10, 1265-1279.

[8] United Nations Department of Economic and Social Affairs (UNDESA). (2018). State of the world population. New York, NY: Author. Available from: https://www.un.org/development/desa/en/news/population/2018-revision-of-world-urbanizationprospects.html.

[9] National Population Commission [NPC]. (2017). Administrative Division. Nigeria: Author. Available from: https://www.citypopulation.de/php/nigeria-admin.php?adm1id=NGA033.

[10] Katharine, H., Scott, S., Laurence, K., Scott, G. (2009). Climate change, heat waves, and mortality projections for Chicago. Journal of Great Lakes Research, 36, 65-73, 2009.

[11] Shahmohamadi, P., Che-Ani, A. I., Ramly, A., Maulud, K. N. A. and Mohd-Nor, M. F. I. (2010). Reducing urban heat island effects: A systematic review to achieve energy consumption balance. International Journal of Physical Sciences Vol. 5 (6), pp. 626-63.

[12] Ojeh, V. N., Balogun, A. A. and Okhimamhe, A. A. (2016). Urban-Rural Temperature Differences in Lagos. Climate, 4(2), 29.

[13] World atlas (2018). Nigeria's Information. Available from: https://www.worldatlas.com/webimage/countrys/africa/nigeria/nglatlog.htm.

[14] Etebong, P. C. (2018). Demography in Nigeria: Problems and Prospects. Biostat Biometrics Open Acc J, 5(1).

[15] World Maps (2018). Nigeria Latitude and Longitude Map. Available from: https://www.mapsofworld.com/lat_long/nigeria-latlong.html

[16] Udo, I.U. and Dickson, B.F. (2017). The Nigerian Aqua-feed Industry, Potentials for Commercial Fed production. Nigerian Journal of Fisheries and Aquaculture, 5(2), 86-95.

[17] Haruna, G., Yacob, M. and Adisa, A. (2015). The Household Cooking Sector in Nigeria: Environmental and Economic Sustainability Assessment. Resources, 4, 412-433.

[18] Edokpa, D. O. and Nwagbara, M. O. (2017). Atmospheric Stability Pattern over Port Harcourt, Nigeria. Journal of Atmospheric Pollution, 5(1), 9-17.

[19] Oyewole, J.A., Thompson, A.M., Akinpelu, J.A. \&Jegede, O.O. (2014). Variation of Rainfall and Humidity in Nigeria. Journal of Environmental and Earth Science, 4(2), 29-37.

[20] Oke, T.R. Review of Urban Climatology 1973 - 1979 (1979). World Meteorological Organization\Technical Note: 169, World Meteorological Organization, Geneva, 100, 1979.

[21] Hoyt, D. (2006). Urban Heat Island and land use changes. Available from: htpp://www.warwickhughes.com/hoyt/uhi.htm

[22] Lemonsua, V., Viguiéb, M. and Daniela, V. M (2015). Vulnerability to heat waves: Impact of urban expansion scenarios on urban heat island and heat stress in Paris (France). Elsevier, 14(4), 586-605.

[23] National Bureau of Statistics [NBS]. (2012). Annual Abstract of Statistics. Nigeria.

Publish your research article in AIJR journals-

$\checkmark \quad$ Online Submission and Tracking

$\checkmark$ Peer-Reviewed

$\checkmark$ Rapid decision

$\checkmark$ Immediate Publication after acceptance

$\checkmark$ Articles freely available online

$\checkmark \quad$ Retain full copyright of your article.

Submit your article at journals.aijr.in
Publish your books with AIJR publisher-

$\checkmark \quad$ Publish with ISBN and DOI.

$\checkmark$ Publish Thesis/Dissertation as Monograph.

$\checkmark$ Publish Book Monograph.

$\checkmark$ Publish Edited Volume/ Book.

$\checkmark$ Publish Conference Proceedings

$\checkmark \quad$ Retain full copyright of your books.

Submit your manuscript at books.aijr.org 